\title{
Adolescent risk-taking: comparison between adolescents' and adults' opinion
}

\author{
Neslihan Güney Karaman \\ Figen Çok \\ Ankara University, Cebeci - Ankara, Turkey
}

\begin{abstract}
Adolescent risk-taking is one of the most important issues in current research on adolescence. This study aimed to exam the opinion of adolescents and adults regarding adolescent risk-taking. A total of 10 adults aged between 40-50 and 10 adolescents aged between 16-19 from middle socio-economic background residing in Ankara, Turkey, were interviewed. Adults' and adolescents' definitions and examples of risktaking, and their perspectives regarding its sources were studied. Interviews were transcribed. Results showed that adolescents' beliefs regarding risk-taking lack a long-term perspective as they do not consider consequences of their actions and future results. Adults' beliefs on adolescent risk-taking seem to be more realistic and more related to life events than that of adolescents. Future research comparing views of both groups is needed.
\end{abstract}

Keywords: Adolescent. Risk-taking. Adolescent perspective. Adult perspective.

\section{Adoção de comportamentos de risco por adolescentes: uma comparação das opiniões de adolescentes e adultos}

Resumo: A adoção de comportamentos de risco pelos adolescentes é uma das principais preocupações na investigação atual sobre adolescência. Este estudo tem como objetivo comparar as perspectivas de adultos e adolescentes sobre adoção de comportamentos de risco pelos adolescentes. Participaram 10 adultos, com idades entre 40 e 50 anos, e 10 adolescentes, na faixa etária de 16 a 19 anos, de nível socioeconômico médio, provenientes da cidade de Ankara, Turquia. As entrevistas transcritas procuraram investigar como adultos $\mathrm{e}$ adolescentes definem o comportamento de risco, exemplos e suas causas subjacentes. Os resultados mostraram que as crenças dos adolescentes sobre adoção de comportamentos de risco não incluem uma perspectiva temporal, nem refletem sobre as possíveis consequiências dos seus atos para o futuro. Em contrapartida, as crenças dos adultos sobre adoção de comportamentos de risco pelos adolescentes parecem ser mais realistas, levando em consideração suas conseqüências para o futuro. São necessários estudos posteriores para comprovar as diferenças entre os dois grupos.

Palavras-chave: Adolescente. Comportamento de risco. Perspectiva do adolescente. Perspectiva do adulto.

\section{Adopción de comportamientos de riesgo por adolescentes: una comparación de las opiniones de los adolescentes y de los adultos}

Resumen: La adopción de los comportamientos de riesgo por los adolescentes es una de las principales preocupaciones en la investigación actual sobre la adolescencia. Esto estudio tiene como objetivo comparar las perspectivas de los adultos y de los adolescentes sobre la adopción de comportamientos de riesgo pelos adolescentes. En esto estudio participarán 10 adultos, con edades entre 40 y 50 años, y adolescentes, entre 16 y 19 años, provenientes del medio socio económico medio, de la ciudad de Ankara, en la Turquía. Las entrevistas realizadas procuran analizar el modo como los adultos y adolescentes definen el comportamiento de riesgo, los ejemplos que ellos dan y las causas que están en su entorno. Las entrevistas fueron transcritas. Los resultados muestran que las creencias de los adolescentes sobre la adopción de comportamientos de riesgo no incluyen una perspectiva en el tiempo, también no hace reflexión sobre las posibles consecuencias de sus actos para el futuro. En contraposición, las creencias de los adultos sobre la adopción de comportamientos de riesgo pelos adolescentes parecen ser más realistas, teniendo en cuenta sus consecuencias para el futuro. Futuros estudios son necesarios para comprobar las diferencias entre los dos grupos.

Palabras clave: Adolescentes. Comportamiento de riesgo. Perspectiva del adulto. Perspectiva del adolescente. 


\section{Introduction}

Adolescence is a period of biological, psychosocial and economic transition. This period bridges childhood to adulthood, and prepares the individual to step into the adult world, in which one faces considerable number of risks. Adolescents also face many challenges in their subsequent development in today's world. Risk-taking has been a major issue in adolescence and is one of the most frequently studied topic in research on adolescence in the last decade. Corben (2001) has noted that risk-taking in adolescence is not only normal, but is also an essential part of learning and personal development. Ligthfoot (1997) has emphasized that taking risks is a natural and necessary part of growing up and risks are declarations of the self, worn like badges of autonomy, defiance, or group membership. Risktaking has been considered a personality characteristic, a learned behavior and a developmental area (Greene, 2000). The lifespan developmental model considers risk-taking a developmental area for adolescents due to the fact that every young person faces certain risk-taking experiences jointly with challenges as part of their development. From this perspective, risks are part of a healthy development (Hendry \& Kloep, 2002).

Risk-taking behavior is very influential and prevalent in adolescents' life. Risk-taking has currently been described by different aspects (risky and protective factors) and by various researchers in the literature. Risk-taking has various dimensions such as health, academic life, sports, etc. According to some researchers, risk-taking is a very common characteristic among adolescents (Scott, 2004; Hendry \& Kloep, 2002; Steinberg, 2002). According to Scott (2004), taking risks appears to be a way of gaining self-understanding towards the main developmental tasks of adolescence such as forming identity and developing autonomy.

Bell and Bell's (1992) explained that risk-taking includes only volitional behaviors in which outcomes remain uncertain with the possibility of an identifiable negative health outcome. Risk-taking behavior emerges especially at the end of adolescence and early adulthood period (Furlong \& Cartmel, 1997; Arnett, 2000). According to Bell and Bell (1992), risk- taking behaviors are initiated during early adolescence with a marked increase in frequency from early to late adolescence, are prevalent in all socioeconomic and racial/ethnic groups, differ by gender and racial/ ethnic groups, and account for greater mobility during adolescence (Irwin \& Millstein, 1986).

Jessor (1998) and some other researchers state that adolescents engage in problematic behaviors to become an adult and a mature person. According to Alexander, Kim, Ensminger, Johnson and Smith (1990) risk-taking is defined as behaviors which threaten health and life. Trimpop (1994) states that risk-taking is any consciously, or non-consciously, controlled behavior with a perceived uncertainty regarding its outcomes, and/or about possible benefits or costs for the physical or psycho-social well-being of oneself or others.

Fuller (1988) emphasized that risk-taking is not only under the control of conscious decision making, but more often, arises out of the individual's conditioning history, and this is often accompanied by the illusion of conscious involvement. According to Zuckerman (1994), risk is as the appraised likelihood of a negative outcome for behavior. Lightfoot (1997, s.22) defines risk-taking behaviors as "volitional, purposive, goal-oriented and carry potential for harm". Health related risky behaviors such as high-speed driving, driving without license, accidents, and also increased use of substances, runaways, poverty, violence etc. have increasingly contributed to today's adolescent risk-taking.

Previous studies such as by Cohn, Macforlane, Yanez and Imai (1995) and Marom, Austin, Fichhoff, Polingen and Quadrel-Jacobs (1993) have already investigated adults' and adolescents' perceptions of adolescent risk-taking. Both studies consider perceptions of adolescents' risk-taking results. Cohn and colls. (1995) found that teenagers were less optimistic about avoiding risks and at greatest risk of misfortunes. Marom and colls. (1993) did not find considerable differences between adults' and adolescents' perceptions of risk. This limited research is very important in terms of understanding the beliefs or views on risk-taking and generational differences, which is quite remarkable in adolescence risk-taking. Those studies seem to totally reflect the western 
image. Risk-taking in adolescence is also one of the most important source of conflicts in adolescents' families. An experience may be considered risky by parents but not by adolescents.

This research is based on the perspectives of adults and adolescents regarding risk-taking. Comparison of both views can contribute to the conceptualization of adolescent risk-taking and be useful to understand how adolescents perceive it.

Research is limited to explain differences between adults' and adolescents' perspectives on risktaking behavior. Furthermore, previous research have often depended on the use of quantitative data. This research attempts to see the difference, (if any) between both perspectives, through the use of qualitative data analysis.

Turkey is a unique country, quite traditional in most aspects regarding adolescence, though Turkish adolescents are very modern and westernalized in some aspects. Thus, this study attempts to compare adults' and adolescents' understanding/conceptions regarding adolescent risk-taking behavior in this cultural context.

The explanation mentioned above reflects how adolescent risk-taking is represented in scientific knowledge. We aim, with this research, investigate the lay perspective.

Adolescents and adults seem to hold different views regarding adolescent risk-taking. While adults consider certain behaviors or engagements as risky for adolescents, they may not be considered even slightly risky in the adolescents' perspective. Egocentrism, sensation seeking, identity explorations are developmental characteristics that encourage adolescents to engage in risky behaviors. On the other hand, in the majority of interactions, adolescents tend to not consider risky behaviors as really risky.

The purpose of this research is to compare the opinion of Turkish adolescents and adults on adolescent risk-taking. Therefore, the following questions were formulated.

What are the "risk definition" of adolescents and adults and examples of risks and personal risks that they have already engaged in and the effects and/or consequences of such risks?
What are the opinions, particularly on adolescents' risk-taking and examples of adolescents' risks?

In what aspects adolescents' and adults' opinion, on adolescents risk-taking and sources of adolescent risk-taking, differ?

\section{Method}

A qualitative study was conducted. Interview was employed because it allows participants to explore opinions about adolescent risk-taking.

\section{Participants}

A total of 10 adults aged between 40-50 and 10 adolescents aged between 16-19 were interviewed. The gender distribution of the research group was five women and five men, six girls and four boys. Participants mainly represent middle socioeconomic background, live in Ankara, Turkey's capital. Adults were highly educated (university degree), adolescents were typical high-school students. All volunteered and were enthusiastic about participating in the study.

Twenty people were recruited by telephone through the researchers personal contacts and adolescents were recruited through high schools' administrations.

\section{Interview procedure}

An appointment for each interview and the nature of the study was explained to the participants by telephone. They were also informed their participation would be voluntary and anonymous, interviews and any other data would be confidential, and that they would be able to withdraw from the study at any moment. A face-to-face meeting was also scheduled afterwards.

The interviews took place either in the participants' offices, schools, or at the university. Interviews were conducted by trained field workers and were audio-taped. The average length of the interviews was between 30 and 50 minutes. Tapes were transcribed verbatim, including non-verbal sounds such as laughter or phone bell. 
A total of 20 one-on-one interviews were conducted. Interviews included definitions and examples, and sources of (i.e. causes, leading factors) adolescent risk-taking. Two co-researchers collaborated in the process of interviews and transcription in addition to the researcher's active role. The research questions were directed to the participants. The analyses were made considering adolescents' and adults' views as separate groups.

\section{Interview guide}

The interview was semi-structured. There were two types of Interviews, one for the adolescents and the other for the adult participants. Both included the same questions, only that the adults' version had a slightly different format. Adolescents were asked about themselves and adults were asked about adolescents. The interview started with the following open-ended question: "What is your definition of risktaking?" Researchers tried to allow participants to feel comfortable during interviews. In case participants did not mention their definition of risk-taking after 10 or 15 minutes, the following topics were prompted by open questions: adventure, chance, danger, thrill, excitement, benefit, cost, hazard. Thus, interviews allowed participants to talk about the risk-taking concept as much as they could.

\section{Analysis}

The interviews transcripts were read several times by the authors. In this study, line by line coding of each interview was used (Richardson, 1996). Categories were built from each question in the ongoing analysis. Finally, some categories were collapsed and reduced in number, while other categories were divided into sub-categories. For example, coding "to act without knowing their decision's result" was categorized as risk definition, "risk is the taste of life or terrific was categorized as an example of risk.

At the end, all interviews were read again to ensure a clear profile of each participant's narrative. The overarching themes emerging from these holistic analyses were again, separately cross-validated by two authors. The quotes selected for this paper, if not otherwise stated; represent typical views related the emerging themes presented in the findings.

\section{Result}

Findings are basically presented as three dimensions: risk-taking definitions, examples of risktaking and sources of adolescents risk-taking.

\section{Risk-taking definitions}

The results of the interviews linked general and basic themes regarding risk-taking. Two main perspectives were chosen, the adults' and adolescents' opinions. General risk-taking according to adults' definitions ranged from negative to positive views. Uncertain ends and results were also emphasized. These were, primarily, positive views since adults focused on how risks can be an encouragement for a better life, to make dreams come true". Risks are "the taste of life". "Without risks life is so predictable". "Risks are inevitable in human life". These are typical examples of positive, usual views of risk-taking.

In terms of negative views, risks are viewed as causing negative consequences and several losses. Finally, uncertainty of risks is also highly mentioned. Uncertainty is usually related to outcomes or results of certain behaviors or engagements.

Risks are the taste of life and are necessary to life. (44 years old)

On the other hand, adolescents beliefs' regarding risk-taking seems to be more abstract. Adolescents' perspectives were not easily classified as positive or negative as those from adults. Rather, they "view risk-taking as behaviors with unknown consequences." Uncertainty is the key term in adolescents' definition.

Adolescents also emphasized that benefits and costs are fifty-fifty in risky behaviors. Danger, thrill, recklessness, sensation are the terms that were also used among adolescents' definitions of risk-taking. Risk is also viewed as living without consideration for the future.

Risk means adventure and thrill. (17 years old) 
As good or bad you take risk, it's like you live adventure or thrill. (17 years old, male)

In short, adults' and adolescents' definitions of risk-taking are quite different. Adults' definitions could be grouped as positive and negative. On the other hand, adolescents' definitions were more abstract, varied and even experiential. However, the risks uncertain nature and their unknown consequences and outcomes were considered by the two groups.

\section{Examples of risk:}

Both adolescents and adults provided examples of risk-taking with some reference to personal risks they had already engaged in. Adult's examples of risktaking were constituted of life experience and were more formal than adolescents'.

Following there are some examples they gave regarding this issue: "...doing something out of the legal system", "human relationships, relationships in the trade", "traffic", "wearing light clothes for adolescence", "decision making", "choosing where to live", economic risks such as investments", "acting just the opposite of what a hierarchically superior person (director, manager, boss, etc) proposes."

Adolescents' examples of risk-taking are also quite varied. The examples reflect adolescents' school life such as hiding school records from parents, choosing multiple-choice questions by chance rather than really knowing answers on a test, cheating on the exams, helping friends during exams.

Examples from their relationships such as asking someone for a date, taking on quarrels or fights to gain the admiration of a girlfriend, acting against social pressures by parents (such as sending SMS messages to a boyfriend through the parents' cell phones, bringing cigarette to home, lying to parents).

Other examples were driving fast, drink-driving, physically hurting someone, lying, arriving late at home, running away from home, getting the family's car while parents are sleeping, betting in sport games, jumping from a trampoline.

Adults' and adolescents' examples are different in terms of representing life and are consistent with the developmental period in which they are. While adults' examples affect their life in terms of investments, essential decisions in life, legal system, etc., adolescents' examples reflect their daily life such as cheating on exams, hiding school records from parents, asking someone for a date, fighting and quarrelling, high-speed driving, lying, running away from home, etc.

Consequences of risk-taking were largely mentioned by adolescents, but not by adults. They stated they get afraid, scared, upset or pleased and excited as consequence. They also said that they often take risks such as trying to smoke and then decide not to smoke; they feel they are very special, distinguished or important as a consequence of risk-taking.

\section{Sources or causes of adolescent risk-taking}

According to adults' beliefs, mainly stated during interviews, adolescents do not consider their risk-taking behaviors as risky. They believe adolescents do not consider risky the behaviors they engaged in. All adults in the study, except one, agreed that adolescents take more risks than adults. The only exception was a women who claimed today's adolescents do not take risks. In her adolescence, which was like 30 years ago, she believed adolescents were more risk-taking, responsible and sensitive to societal issues. She maintained today's adolescents were individualistic and did not hold cooperative values. Adults find adolescents excited, having many and unrealistic expectations. In their adolescence hopes were too exaggerated.

Adults think adolescents are not sufficiently mature and rational; they think adolescents only focus on the present time rather than on the future. The sources or causes of these characteristics were also asked during the interviews. Adults mentioned many developmental characteristics of adolescents as causing risk-taking such as self-reliance, confidence, need for freedom, independence, being inexperienced, need to get known and popular. They also stated that adolescents are curious about the world, are enthusiastic, seek novelty and sensation and are hedonistic and courageous. They also pointed their thrill and adventure-seeking nature. 
They think that I can try it once and don't be afraid of it. (45 years old)

They don't think about future or past, they engage in it now and lack concern about long-term consequences. (48 years old, female)

Adolescents think that they won't be affected by consequences of risk-taking. (45 years old)

Adolescents don't realize the risky behavior they have engaged before. (48 years old, female)

Adolescents' opinions about sources of adolescent risk-taking seem more optimistic and hopeful. They reported the influence of friends (peer pressure), the nature of the period of adolescence itself. They specifically focused on the excitement itself, emphasizing the increase of adrenaline in risktaking behaviors. Other views, regarding adolescents' risks, consider adolescents' obstinate and pleasureseeking nature and feeling of knowing it all. They maintained that risks alleviate boredom and make life more enjoyable.

It helps me to escape from the boredom of nareal life. (16 years old)

Thus, two different pictures of sources of adolescent risk-taking have been proposed by adults and adolescents. While adults think that adolescent risk-taking depends on adolescents' lack of experience and maturity, lack of consideration for long-term consequences, characteristics and exaggerated hopes, adolescents emphasize excitement, pleasure, sensation and the novelty-seeking and funny nature of adolescents. On the other hand, the two age groups agreed that adolescents are more prone to risk-taking than adults.

I guess I won't enjoy such risks after 10 years from now. There are lots of risks during "adolescence" period. (18 years old) I want to try anything I can. (17 years old) It gives me great excitement. (18 years old) It is Important to enjoy every moment of life. (48, years old, female)
I don't believe that I may get hurt, adrenaline or excitement is important to me. (16 years old)

While adults' opinions seems to relate to the results of behaviors, adolescents' perspective is focused on the risk-taking process. That is, in the adolescents' perception, getting involved in risky behaviors is so attractive it diminishes the importance of potential negative results. They never consider potential threats to their lives.

We think that we know the best of everything and do not consider bad things as a consequence. We'd like experiment everything. (18 years old)

\section{Discussion}

The study shows that adolescents and adults differ in their risk-taking definitions in many aspects. The developmental characteristic underlying the difference of opinions is considered. Adolescents are developmentally egocentric (Elkind, 1967; Hendry \& Kloep, 2002). Literature has pointed certain determining factors of adolescent risk-taking; seeking thrill, calculation, audience control, irresponsible behavior (Hendry \& Kloep, 2002; Arnett, 1992). Adults' opinion about adolescent risk-taking has not been a question studied in the literature.

Regarding risk-taking definition, compared to adults, adolescents consider benefits and costs are fifty-fifty in risk-taking behaviors. They also believe risk-taking is mainly a long-term process considering the consequences of their actions and future results. Adolescents' conceptions related to risk definition include some characteristics such as danger, thrill, recklessness and sensation. The other differences in adolescents' opinions regarding risk-taking is that adolescents' definitions are more abstract.

Adolescents provided diverse examples of risktaking in this study such as, hiding school records from parents, physically hurting someone, lying, arriving late at home, running away from home, and taking family's car while parents were sleeping. Adolescents want to experience sensations, fun, color in their daily "routine" and experience risk themselves. Adolescents 
seem to be seeking novelty and sensation (Arnett, 1992) in their life.

Adults' examples of risk-taking relate to personal risks they had already engaged in, which is generally linked to their work and "serious issues" and "under their control". However, adults" examples of adolescent risk-taking are related to irresponsible behavior, thrill and excitement that only provide fun in the short-term.

Another divergent point in adults' and adolescents' opinions is that adults seem to view adolescents more risk taker than adults. Adolescents believe that they take more risks than adults. Peer pressure, seeking new experiences such as, sensation/ thrill/ novelty seeking may contribute to the differences, as to be egocentric and feel invulnerable. Lapsley and Murphy (1985) presented the term invulnerability in adolescent egocentrism which could be experienced "I feel that I don't suffer".

The comparison between adults' and adolescents' perspectives on adolescent risk-taking may contribute to the current literature. In addition, other studies on the perspectives of adolescent risktaking can also contribute to the understanding of adolescent risk-taking. Further research is needed with data from different groups of adolescents and also from other cultures.

\section{References}

Alexander, C. S., Kim, Y. J., Ensminger, M., Johnson, K. E., Smith,B. J., \& Dolan, L. (1990). A measure of risk raking for young adolescents: Reliability and validity assessments. Journal of Youth and Adolescence, 19(6), 559-569.

Arnett, J. (1992). Review: Reckless behavior in adolescence: A developmental perspective. Developmental Review, 12(4), 339-373.

Arnett, J. J. (2000). Emerging adulthood: A theory of development from the late teens thought the twenties. American Psychologist, 55(5), 469480 .

Bell, N., \& Bell, R. (1992). Adolescent risk taking. Newbury Park, CA: Sage Publication.
Cohn, D. L., Macfarlane, S., Yanez, C., \& Imai, W. K. (1995). Risk-perception: Differences between adolescents and adults. Health Psychology, 14(3), 217-222.

Corben, M. (2001). Risk taking in adolescence risk seminars: RRISK online forum. Retired in 15th june 2003, of http://www2b.abc.net.au/northcoast/ risk.

Elkind, D. (1967). Adolescence egocentrism. Child Development, 38, 1025-1034.

Fuller, R. (1988). On learning to make risky decisions. Ergonomics, 31(4), 519-526.

Furlong, A., \& Cartmel, F. (1997). Young people and social change: Individualization and risk in late modernity. Buckingham, UK: Open University Press.

Greene, K., Krcmar, M., Walters, L.H., Rubin, D.L., Hale, J. and Hale, L. (2000). Targeting adolescent risk taking behaviors: The contributions of egocentrism and sensation seeking, Journal of Adolescence, 23, 439-461.

Hendry, L., \& Kloep, M. (2002). Life span development: Resources, challenges and risks. London, England: Thomson and Learning Press.

Irwin CE Jr, Millstein S.G. (1986). Biopsychosocial correlates of risk-taking behaviors during adolescence. Journal of Adolescence Health Care, 7, 82-96.

Jessor, R.(1998). New Perspective on Adolescent Risk Behavior. New York : Cambridge University Press.

Lapsley, D. K., \& Murphy, M. N. (1985). Another look at the theoretical assumptions of adolescent egocentrism. Development Review, 5, 201-217.

Lightfoot, C. (1997).The culture of adolescent risktaking. New York: The Guildford Press.

Marom-Beyth, R., Austin, L., Fischoff, B., Palmgren, C., \& Quadrel-Jacobs, M. (1993). Perceived consequences of risky behaviors: Adults and adolescents. Developmental Psychology, 29(3), 549-563. 
Richardson, J. T. E. (1996). Handbook of qualitative research methods for psychology and the social sciences. Leicester, UK: BPS Books.

Scoot, D. (2004). Reduction of risk behaviors in youth including: Risk taking. Retirado em 20 março 2004, de http://ag.arizona.edu/fcs/cyfernet/ nowg/ythrisktake.html.

Steinberg, R. (2002). Adolescence (6th ed.). New York: McGraw-Hill Higher Education.

Trimpop, R. M. (1994). The psychology of risk taking behavior. Amsterdam: North- Holland.

Zuckerman, M. (1994). Behavioral expression and biosocial bases of sensation seeking. New York: Cambridge University Press.

Artigo recebido em 01/08/2006.

Aceito para publicação em 09/06/2007.

Endereço para correspondência:

Figen Çok. Ankara University, Faculty of Educational Sciences. Cebeci-Ankara. E-mail: figen.cok@gmail.com

Neslihan Güney Karaman is $\mathrm{PhD}$ in Educational Psychology in Ankara University.

Figen Cok is professor of Educational Psychology in Ankara University. 